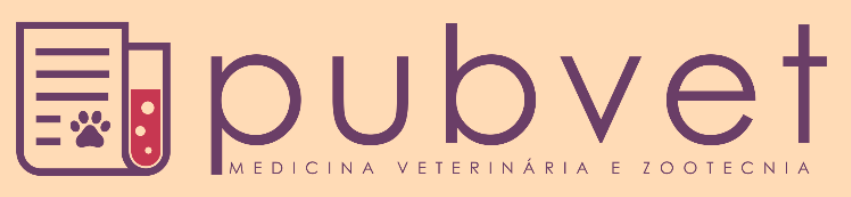

https://doi.org/10.31533/pubvet.v14n11a695.1-11

\title{
Economic aspects of control and eradication of bovine tuberculosis and the managerial costs associated: Review
}

\author{
Luciana dos Santos Medeiros ${ }^{19}$, David Ashford ${ }^{2}$, Rui Carlos Peruquetti ${ }^{1 \oplus}$, Susan Christina

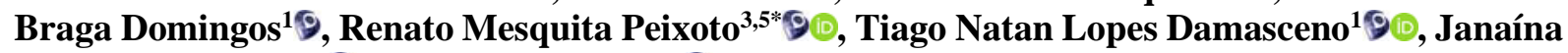 \\ Valente dos Santos $^{10}$, Walter Lilenbaum ${ }^{4}$, \\ ${ }^{1}$ Laboratory of Veterinary Immunology and Microbiology, Unit of Teaching and Research in Veterinary Medicine, Acre Federal University, \\ Industrial District, Rio Branco, Acre, Brazil. \\ ${ }^{2}$ Kansas State University, Manhattan. \\ ${ }^{3}$ Department of Animal Health, Embrapa Goats and Sheep/CNPC, Road Sobral-Groaíras, Countryside, 62010-970, Sobral, Ceará-CE, Brazil. \\ ${ }^{4}$ Laboratory of Veterinary Bacteriology, Biomedical Institute, Fluminense Federal. University, 101 Prof. Hernani Mello Street, Niterói, Rio de Janeiro, Brazil. \\ ${ }^{5}$ Scholarship for Regional Scientific Development of the National Council for Scientific and Technological Development (DCR- \\ CNPq/FUNCAP), level C, 38706-400, Brasilia, Distrito Federal-DF, Brazil. \\ *Autor para correspondência, E-mail: renatomiraima@gmail.com
}

\begin{abstract}
Given its importance in veterinary medicine and its impact on human health, bovine tuberculosis demands attention on animal health programs in several countries. New ante- and post-mortem diagnosis protocols are available and facilitate disease detection and control. However, besides the known advantages and disadvantages of each protocol, there is little mention of their costs. This study intends to provide an overview of the economic aspects of diagnostic tests for the control and eradication of bovine tuberculosis.
\end{abstract}

Keywords: diagnosis, programs, tuberculosis

\section{Aspectos econômicos do controle e erradicação da tuberculose bovina e os custos gerenciais associados: Revisão}

Resumo. Dada sua importância na medicina veterinária e seu impacto na saúde humana, a tuberculose bovina exige atenção em programas de saúde animal em vários países. Novos protocolos de diagnóstico ante e post mortem estão disponíveis e facilitam a detecção e controle de doenças. No entanto, além das vantagens e desvantagens conhecidas de cada protocolo, há pouca menção sobre seus custos. Este estudo pretende fornecer uma visão geral sobre os aspectos econômicos dos testes de diagnóstico para controle e erradicação da tuberculose bovina.

Palavras chave: diagnóstico, programas, tuberculose

\section{Aspectos económicos del control y la erradicación de la tuberculosis bovina y los costos de gestión asociados: Revisión}

Resumen. Dada su importancia en la medicina veterinaria y su impacto en la salud humana, la tuberculosis bovina requiere la atención de los programas de salud animal en varios países. Los nuevos protocolos de diagnóstico antes y después de la muerte están disponibles y facilitan la detección y el control de enfermedades. Sin embargo, aparte de las ventajas y desventajas de cada protocolo, hay poca mención de sus costos. Este estudio tiene como objetivo proporcionar una visión general de los aspectos económicos de las pruebas de diagnóstico para controlar y erradicar la tuberculosis bovina.

Palabras clave: diagnóstico, programas, tuberculosis 


\section{Introduction}

Bovine tuberculosis affects several animal species, and it's considered a zoonosis. Its causal agent is Mycobacterium bovis, an acid-fast resistant bacillus (Eisenstadt \& Hall, 1995; Olea-Popelka et al., 2017). The disease frequently attacks the lungs, but an intestinal form may occur in calves after the ingestion of contaminated milk (Biffa et al., 2012). Human contamination may occur via airborne, ingestion of infected milk or, less frequently, by contact with mucous membranes and damaged skin (Thoen et al., 2009; Vordermeier et al., 2012). Although in humans tuberculosis caused by $M$. tuberculosis or by M. bovis are indistinguishable (Allix-Beguec et al., 2010), bovine tuberculosis can produce extrapulmonary symptoms due to oral infection associated with raw dairy products ingestion, a common situation in less developed countries (Katale et al., 2012).

Given its importance in veterinary medicine and its impact on human health, bovine tuberculosis demands attention from animal health programs in several countries. However, limitations of the current diagnosis methods contribute to unsuccessful agendas for bovine tuberculosis prevention and control in several places around the world (Waters et al., 2011). To solve the problem, governmental agencies or research institutes have developed alternative approaches and diagnostic protocols. These protocols may include the dosage of interferon-gamma (IFN) (Clegg et al., 2017; Rangen et al., 2009; Wood et al., 1990), ELISA for the detection of anti-M. bovis antibodies (Casal et al., 2017; Marassi et al., 2011; Waters et al., 2006), use of polymerase chain reaction (PCR) technology (Diallo et al., 2016; Wards, 1995; Yahyaoui-Azami et al., 2017; Zumárraga et al., 2012), histopathology (Palmer et al., 2006; Piercy et al., 2007; Silva, 2001) and culturing procedures (Corner et al., 2012; Yates et al., 2017), more often used in a multidisciplinary diagnostic strategy (Marassi et al., 2013).

Considering all the aspects related to bovine tuberculosis's control and eradication, it is important to discuss the financial aspects (if they exist) of the available protocols. This study presents an extensive literature review on how countries succeed or not in combating bovine tuberculosis, our focus is on the economic aspects.

\section{Methodology}

We survey the scientific literature on bovine tuberculosis, the associated eradication programs and the costs for its diagnose. Classical bibliographies were also consulted to establish concepts of the subject along with the text. We used online databases (PubMed, Lilacs, SciELO, and Periódico CAPES) to find proper papers published between 1990 and 2014. The search terms were 'cost-effectiveness AND tuberculosis', 'cost-benefit AND animal', 'cost-benefit AND tuberculosis', 'veterinary AND economics', and 'tuberculosis AND costs'. The survey was performed between January 2018 and July 2018 and only papers or books in Portuguese or English were considered.

\section{Systematic review: main data}

A total of 69 articles were retrieved from online sources, of which 40 articles were selected for data extraction based on the specified inclusion criteria. From these selected published articles, we could find that the majority of papers regarding economical aspects of bovine tuberculosis were published in Brazil (40\%) and United Kingdom (27,5\%) (Figure 1). Not surprisal the bovine Tb continuous to be an important burden to animal health and agribusiness in these countries (Bennett \& Cooke, 2006; Bernués et al., 1997; Broughan et al., 2016; Conlan et al., 2018; Marassi et al., 2010, 2013; Medeiros et al., 2012).

From all of those papers, we could identify four main issues: Aspects of general economic analysis, Cost-benefit analysis, Cost-effectiveness analysis, and Bovine Tb diagnosis. In this sense, the majority were related to the aspects of general economic analysis (32.5\%) and Bovine Tb diagnosis (45\%) (Figure 2). These results show a lack of specialized literature concerning cost-effectiveness and cost-benefit analysis of bovine $\mathrm{Tb}$ control. 


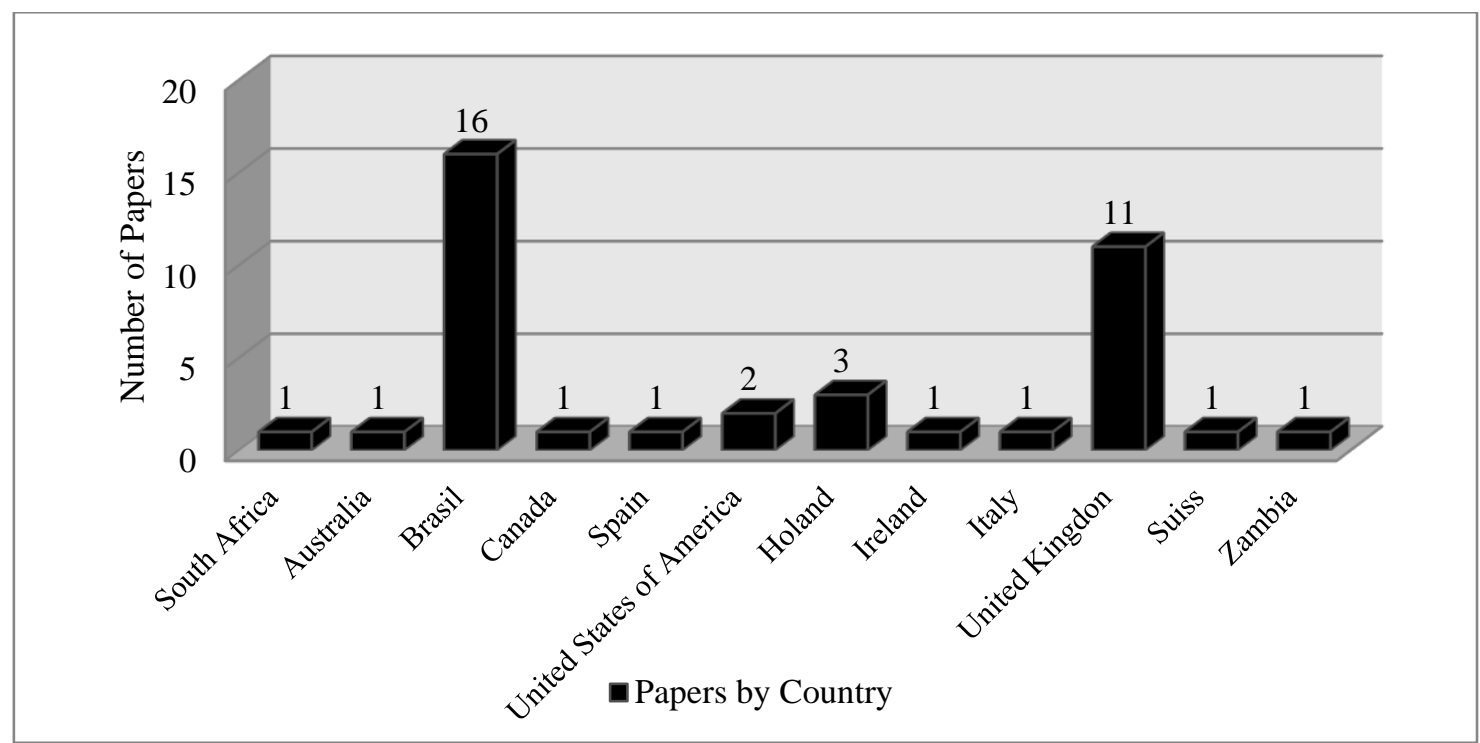

Figure 1. Number of papers by country published between 1990 and 2014 .

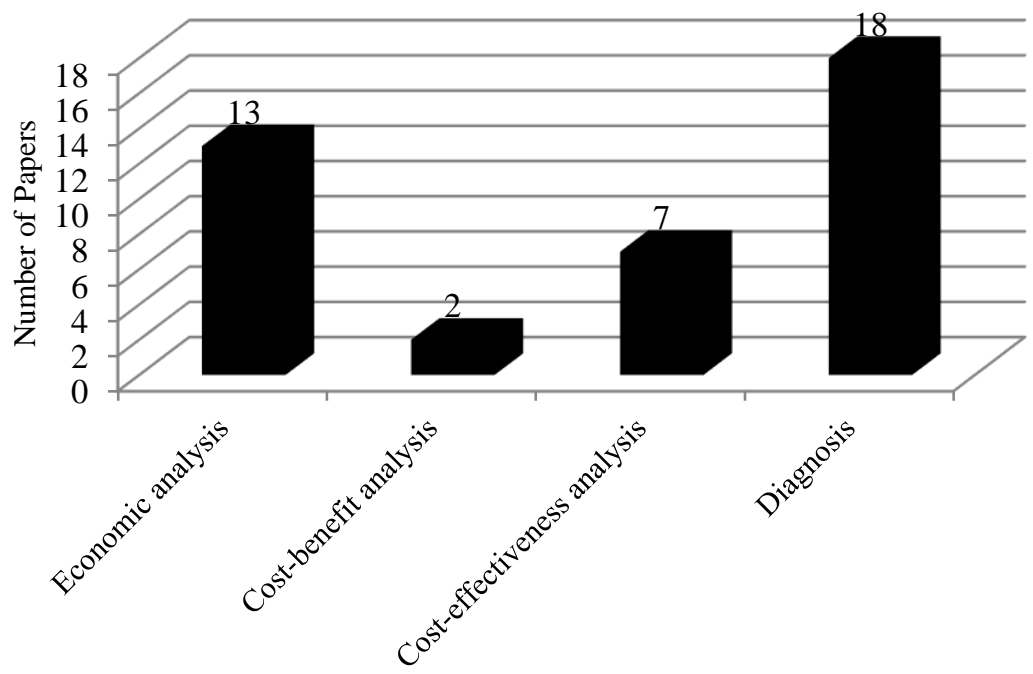

- Papers by Issue

Figure 2. Number of papers by issue published between 1990 and 2014.

\section{Bovine tuberculosis: current strategies and their problems}

Diagnostic tests for the control and eradication of bovine tuberculosis should consider both ante- and post-mortem procedures to (i) detect the disease in the herd, (ii) eliminate infected animals, (iii) confirm and identify the etiologic agent, and (iv) contribute to their epidemiological knowledge. Tests fall into two categories: indirect tests (which measure the animal immune response to a known antigenic stimulus) and direct tests (which detect etiologic agents). The association between direct and indirect tests make it possible to detect infected animals and to identify M. bovis strains. Countries that successfully eradicated bovine tuberculosis created programs that combined at least two diagnostic tests (as intradermal tests and IFN), rather than individual diagnosis (Rua-Domenech et al., 2006; $\underline{\text { Schiller et }}$ al., 2010). Many authors agree that no diagnostic method alone can diagnose all animals infected with M. bovis (Lilenbaum et al., 2001; Lilenbaum \& Fonseca, 2006; Marassi et al., 2010, 2013; Medeiros et al., 2012; Medeiros et al., 2010).

Eradication strategies with high accuracy at the individual level have been proposed (Schiller et al., 2010), such as targeted control systems and ancillary tests. New strategies and the development of better diagnostic techniques also help the control of human tuberculosis (Walzl et al., 2018). Examples are: (a) vaccination with an attenuated strain of $M$. bovis Bacillus Calmette Guerin, (b) use of tuberculin for in vivo diagnosis, and (c) measurement of IFN in vitro as a biomarker of infection. Bovine tuberculosis 
eradication supposes the incorporation of new technologies into traditional eradication campaigns and consideration of different epidemiological disease aspects (Schiller et al., 2010).

The diagnosis of bovine tuberculosis is badly understood, thus further studies are necessary on the microbiology and immunology of M. bovis (Marassi et al., 2013; Pollock et al., 2005; Pollock \& Neill, 2002; Waters et al., 2011; Yates et al., 2017). Additionally, some authors suggest that diagnostic methods or techniques used to monitor bovine tuberculosis need a multidisciplinary approach often in multiple steps, given the differences in immune responses between animals (Marassi et al., 2013; Medeiros et al., 2010).

\section{Costs and benefits of bovine tuberculosis elimination}

A strong factor in the economic effectiveness of eradication programs is the prevalence of the disease, through the financial burden of compensation for infected animals slaughtered. More often, whether the prevalence of a disease increase, the costs of its eradication rise accordingly (Bennett \& Cooke, 2006; Bernués et al., 1997).

By 2015, more than 35,000 animals were identified and slaughtered in Britain following the same policy practiced in the United States. The main goal, besides the eradication of the disease in the herds, is the clinical certificate of TB free zone, which is economically more advantageous (Broughan et al., 2016; Conlan et al., 2018).

Given the increase in case numbers of bovine tuberculosis along years, despite an eradication program, the department for environment, food and rural affairs of England (DEFRA) requested in 2004 an evaluation of the economic impact of the disease on the country's economy (Bennett \& Cooke, 2006). The conclusion was that four main costs were associated with an outbreak of bovine tuberculosis and its control: test, isolation, movement restrictions, and animal slaughter (Bennett, 2009; Bennett \& Cooke, 2006).

In the United States, an eradication campaign based on 'test and slaughter' began in 1917. In economic and health terms, the campaign was a success (Gilsdorf et al., 2006). Since its beginning, the country has had an estimated benefit of approximately two million dollars per year, even ignoring falling export rates caused by bovine tuberculosis, which rise the program costs because of losses in productivity. Productivity loss represents a direct large financial burden on farmers and international trade of products as meal and milk. In the American scenario, bovine tuberculosis rose production costs proportionally to its prevalence. Thus, the economic success of the program refers only to decreasing bovine tuberculosis prevalence among domestic and wild animals and low cost for its control (Gilsdorf et al., 2006).

In Australia, the control program of brucellosis and tuberculosis began in the 1930s, initially based on surveillance mechanisms in slaughterhouses. From the 1940s, milk pasteurization and tuberculin tests for diagnosing bovine tuberculosis were routine. However, the Australian national eradication program ('test and slaughter' based) started only in 1970. The country was declared free of bovine tuberculosis in 2006, with a consequent increase in cattle management efficiency and farm productivity. Such a situation benefitted the Northern countryside with great financial rewards (Turner, 2011).

Despite the positive results in the United States and Australia, control programs of brucellosis and tuberculosis showed a negative cost-benefit ratio in Spain (Bernués et al., 1997). There, the brucellosis program was economically efficient over a long time, but the bovine tuberculosis program did not. Despite economic problems, the analysis did not consider the prevention of zoonosis and costs associated with the diagnosis and treatment of tuberculosis in humans, what is common for many eradication programs of animal diseases (Bernués et al., 1997; Smith \& Clifton-Hadley, 2008; Torgerson \& Torgerson, 2009). Yet Torgerson \& Torgerson (2008) cast doubts on economic terms related to the control of bovine tuberculosis, because bovine tuberculosis prevalence increased in recent years, while zoonotic tuberculosis did not. Other authors argue that the implemented eradication strategies are the reason for low bovine tuberculosis prevalence in humans Tuberculosis: a re-emerging disease in animals and humans (Gordon, 2008; Smith \& Clifton-Hadley, 2008; Thoen et al., 2009). 
Van Asseldonk et al. (2005) constructed a stochastic cost-efficiency bioeconomic model to determine the best program for surveillance of bovine tuberculosis in Holland. The authors concluded that compared with the other five models the surveillance of injury carcasses model was the best. Although inspections at slaughterhouses showed better results in this model, testing and slaughter costs depend on the disease prevalence and the chosen method depends on the objectives of the control and eradication program.

Regardless numerous studies on the validity and effectiveness of bovine tuberculosis diagnosis (Marassi et al., 2013; Monaghan et al., 1994; Schiller et al., 2010; Waters et al., 2011), few data are available for estimating bovine tuberculosis diagnosis costs (Moraes et al., 2006; Vanni et al., 2009). In addition, there is only one literature about the Brazilian analysis of cost-effectiveness for bovine tuberculosis, even after more than one decade of implementation of the National Program for Control and Eradication of Brucellosis and Tuberculosis (PNCEBT) (Medeiros et al., 2016). In that study, the authors evaluated the cost-effectiveness of bovine tuberculosis diagnostic protocols on a multidisciplinary approach, applied in a naturally infected herd. Regarding the cost-effectiveness analysis of antemortem diagnostic protocols, the Cervical Comparative Test, when used alone, is the diagnostic protocol most cost-effective for a naturally infected herd. For post-mortem confirmatory diagnostic, the histopathology associated with the Cervical Simple Test and Cervical Comparative Test was the most cost-effective choice for the animals studied in this herd. However, the only diagnostic protocol that was able to identify $100 \%$ of the infected animals was the ELISA associated with the IFN test (Medeiros et al., 2016). However, despite these valuable new results on the economic analysis of diagnostic costs, it is necessary that this evaluation be expanded considering different productive and economic models. Thus, we consider necessary to perform an economic evaluation of the impacts of bovine tuberculosis outbreak in more farms, including costs associated with diagnosis of naturally infected animals. Unfortunately, there is not a standardized process to determine current costs of tuberculosis outbreaks and its diagnosis. Unfortunately, sometimes costs are calculated using only published data together with information provided by farmers or experts (Bennett \& Cooke, 2006). This fact may underestimate the costs of the diagnostic processes, affecting the whole program of control and eradication of bovine tuberculosis.

\section{Classification of costs in animal health}

Costs are part of production theory, always associated with the idea of losses in resources and so usually valued. This makes them an important consideration in decision-making and that is why each manager keeps in mind the question: how much should we produce to keep our costs low and to raise our profit? (Samuelson \& Marks, 2012; Vanni et al., 2009). Here we give an overview of costs we consider important to animal health rather than an extensive review of cost-utility analysis, which can

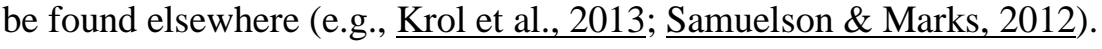

Costs are divided into two groups: fixed and variable. Fixed costs do not vary with the amount of production, thus they are constant with respect to different courses of action under consideration, being irrelevant and need not be considered by the managers (Samuelson \& Marks, 2012). According to Samuelson \& Marks (2012), the reason is simple enough: If managers compute each alternative's profit (or benefit), the same fixed cost is subtracted in each case. Therefore, the fixed cost itself plays no role in determining the relative merits of the actions. These authors also say that doing so managers focus on the differential costs that are relevant, but it is known that ignoring fixed costs is easier in principle than in practice. Variable costs relate to expenditures on variable inputs. Thus, variable costs rise with increases in the quantity of output. Variable costs are much more variable with time than the quantity of product produced, as variable costs vary with the level of production and are subject to change on short notice. In the long run, all costs are variable because all inputs can vary freely; at this point, there is no difference between the sum of fixed cost and variable cost (total cost) and variable costs itself (Samuelson \& Marks, 2012).

Variable costs can encompass both costs that are directly related to production, benefit, or intervention proceeds (direct costs - i.e., diagnostic tests, animal slaughter, salary expenses, etc.) and costs that did not directly relate to intervention proceeds (indirect costs - i.e., productivity lost, infection risks, etc.). In addition, variable costs can also include costs that cannot be or are badly valued 
(intangible costs). Intangible costs may involve measures of suffering because of the disease (e.g.), and although some managers find intangible costs implicit in indirect costs calculus (because suffering or any discomfort contribute to lower productivity), they are not considered in traditional animal health programs, but they are considered in programs that use cost-effectiveness analysis (see below). Such programs include concepts of productivity costs, a term not related to costs of production (i.e. the sum of all possible cost of producing any given level of output). Productivity costs are associated with production loss and replacement costs due to illness, disability, and death (of productive persons, both paid and unpaid) (Brouwer et al., 1997). Given its complexity and difficulty to transpose such a concept into animal production systems, productivity cost usually is excluded from the economic evaluation of animal health (Sancho, 2008). Even for human health programs, a debate exists on the inclusion or not of productivity costs in economic evaluations (see definition below). The main problems consist of how to identify, measure, and value productivity costs. Krol et al. (2013) present a good review of the topic.

\section{Costs involved in animal health}

Krol et al. (2013) give us the following definition of economic evaluations: 'the comparative analysis of alternative courses of action in terms of both their costs and consequences'. Although at least four types of economic evaluation can be identified, all of them express costs in monetary units but differ in the way they express the benefits.

The first type of economic evaluation is the traditional cost-benefit analysis in which costs and effects are expressed in monetary terms. This analysis is common in animal health programs because of an established practice in the evaluation of projects involving capital investment, thus it relates directly to monetary returns or net benefits (Mwacalimba et al., 2013). This analysis may compare various treatments for clinical indications. After the analysis, the intervention with greater benefit is preferred.

The second type of economic evaluation, cost-utility analysis, is not used in animal health, yet it has /become popular in human health (Krol et al., 2013). The cost-utility analysis uses a measure expressed in quality-adjusted life years (QALYs) that consider both lengths of life and quality of life. The third type, also not used in animal health programs, is cost-minimization analysis (CMA). This analysis considers only costs, not health effects. Its use is only appropriate when there is no significant difference in terms of health benefits ( Krol et al., 2013).

The fourth analysis (cost-effectiveness analysis) expresses costs in monetary terms, but the effects are expressed in natural (clinically relevant) units such as avoided injuries or the number of successfully treated patients. The cost-effectiveness analysis is appropriate to compare strategies with different costs and effectiveness. The analysis allows identifying interventions with the greatest health impact and lowest cost. In this sense, a cost-effective test is not necessarily the cheapest one (Sohn et al., 2009). Overall, cost-effectiveness analysis using at least one alternative procedure as a reference, which represents a current protocol or standard drug (Secoli et al., 2010). However, cost-effectiveness analysis may make manager decisions difficult given the incomparability of outcome measures and results (Krol et al., 2013). Understanding the methodologies of cost-effectiveness, studies are critical to conducting a proper judgment about total costs and cost-effectiveness of alternative diagnostic tests. Different methodologies produce distinct total costs and therefore distinct cost-effectiveness, reflecting the way we collected and interpret data (Sancho, 2008; Sohn et al., 2009). The case of human tuberculosis diagnostic systems is an example of how different research groups may distinctly evaluate costs (details in Sohn et al., 2009). Differences we detect comparing methods of cost estimation relate likely to regional characteristics and data availability for each study (Segala \& Silva, 2007).

Nevertheless, some studies consider both cost-benefit and cost-effectiveness analysis in veterinary medicine (Sohn et al., 2009; Van Asseldonk et al., 2005). Regarding diagnostic methods, both analyses are crucial for decision-making in programs of prevention and eradication of diseases, as they take into account both the possibility of animal treatment or slaughter.

Costs can be estimated using different methodologies. In animal health programs generalizations and secondary data are widely accepted to estimate costs (Bennett \& Cooke, 2006). However, these authors consider it important to use data from farms with animal health problems, so all costs (e.g. testing procedures costs, isolation costs, and slaughter costs) may be effectively evaluated over time. Such an 
approach may create a debate on the value of statistical methods that generalize results of unlike realities, as costs vary following geographical location, demographic questions, epidemiological interpretations, and time (Sancho, 2008; Sohn et al., 2009). Additionally, Sohn et al. (2009) suggest that to avoid or minimize variation, all considered cost for animal health program/project should be estimated for the year on which the study was conducted. This might diminish any disagreement among alternative diagnoses. Costs should be determined at market prices, making possible updates simple.

\section{Costs involved in eradication programs}

The economic evaluation of eradication programs resides primarily in the identification of costs to eradication or control of a particular disease. Any intervention cost (e.g. a diagnostic test) has in its composition the study perspective and the identification of the intervention effects on changing health status. This allows managers to identify, include or exclude, assess, and appraise resources (Caminiti et al., 2017; Sancho, 2008). In quantitative terms, the costs and the consequences of alternative diagnoses vary depending on the adopted perspective, which may reflect a vision of society or public services (Vanni et al., 2009).

The costs of an eradication program include payment of professional service officers and equipment used in the daily operations, costs of laboratory resources, and compensation to owners of condemned animals. Additionally, there are farmer costs, such as the use of labor force in handling animals and losses in meat or milk production through stress management (Gilsdorf et al., 2006). Training and technical support costs are frequently ignored (Sohn et al., 2009). Recently, a study conducted by Caminiti et al. (2017) evaluated the costs involved in the tuberculosis eradication program for cattle in Italy. The above-mentioned costs were not included in the analysis for lack of relevance, except those related to the slaughter of animals.

It is important to emphasize that in a program to eradicate bovine tuberculosis the costs directly related to testing procedures, given that testing after animal slaughter contributes greatly to the outbreak cost formation (Bennett \& Cooke, 2006). Farmers argue that the use of employees to manage animals and help testing procedures sharply increase testing costs (Bennett, 2009). However, test value for each animal varies according to the number of tested animals, so that the greater the number of tested animals, the smaller the cost of a diagnostic test (Bennett, 2009; Bennett \& Cooke, 2006). The costs associated with eradication programs may also become lower when the official disease-free zone certificate is obtained, as the frequency of testing and the population tested may be reduced (Caminiti et al., 2017).

\section{Conclusions}

Strategies to establish correlations between good detection of infected animals and cost-suited tests become relevant. Additionally, considering all the aspects related to bovine tuberculosis's control and eradication, it is important to discuss the financial aspects of the available protocols.

\section{Acknowledgments}

To CNPq - National Council for Scientific and Technological Development and UFAC - Federal University of Acre for granting scholarships.

\section{Conflict of interest statement}

The authors declare that they have no conflict of interest.

\section{References}

Allix-Beguec, C., Fauville-Dufaux, M., Stoffels, K., Ommeslag, D., Walravens, K., Saegerman, C., \& Supply, P. (2010). Importance of identifying Mycobacterium bovis as a causative agent of human tuberculosis. European Respiratory Journal, 35(3), 692-694. https://doi.org/10.1183/09031936.00137309

Bennett, R. M. (2009). Farm costs associated with premovement testing for bovine tuberculosis. Veterinary Record, 164(3), 77-79. https://doi.org/10.1136/vr.164.3.77

Bennett, R. M., \& Cooke, R. J. (2006). Costs to farmers of a tuberculosis breakdown. Veterinary Record, 
158(13), 429-432. https://doi.org/10.1136/vr.158.13.429

Bernués, A., Manrique, E., \& Maza, M. T. (1997). Economic evaluation of bovine brucellosis and tuberculosis eradication programmes in a mountain area of Spain. Preventive Veterinary Medicine, 30(2), 137-149. https://doi.org/10.1016/S0167-5877(96)01103-8

Biffa, D., Bogale, A., Godfroid, J., \& Skjerve, E. (2012). Factors associated with severity of bovine tuberculosis in Ethiopian cattle. Tropical Animal Health and Production, 44(5), 991-998. https://doi.org/10.1007/s11250-011-0031-y

Broughan, J. M., Judge, J., Ely, E., Delahay, R. J., Wilson, G., Clifton-Hadley, R. S., Goodchild, A. V., Bishop, H., Parry, J. E., \& Downs, S. H. (2016). A review of risk factors for bovine tuberculosis infection in cattle in the UK and Ireland. Epidemiology and Infection, 144(14), 2899-2926. https://doi.org/10.1017/S095026881600131X

Brouwer, W. B. F., Koopmanschap, M. A., \& Rutten, F. F. H. (1997). Productivity costs in costeffectiveness analysis: numerator or denominator: a further discussion. Health Economics, 6(5), 511514. https://doi.org/10.1002/(SICI)1099-1050(199709)6:5<511::AID-HEC297>3.0.CO;2-K

Caminiti, A., Pelone, F., Battisti, S., Gamberale, F., Colafrancesco, R., Sala, M., La Torre, G., Della Marta, U., \& Scaramozzino, P. (2017). Tuberculosis, Brucellosis and Leucosis in Cattle: A Cost Description of Eradication Programmes in the Region of Lazio, Italy. Transboundary and Emerging Diseases, 64(5), 1493-1504. https://doi.org/10.1111/tbed.12540

Casal, C., Infantes, J. A., Risalde, M. A., Díez-Guerrier, A., Domínguez, M., Moreno, I., Romero, B., Juan, L., Sáez, J. L., Juste, R., Gortázar, C., Domínguez, L., \& Bezos, J. (2017). Antibody detection tests improve the sensitivity of tuberculosis diagnosis in cattle. Research in Veterinary Science, 112, 214-221. https://doi.org/10.1016/j.rvsc.2017.05.012

Clegg, T. A., Good, M., Doyle, M., Duignan, A., More, S. J., \& Gormley, E. (2017). The performance of the interferon gamma assay when used as a diagnostic or quality assurance test in Mycobacterium bovis infected herds. Preventive Veterinary Medicine, 140, 116-121. https://doi.org/10.1016/j.prevetmed.2017.03.007

Conlan, A. J. K., Vordermeier, M., Jong, M. C., \& Wood, J. L. (2018). The intractable challenge of evaluating cattle vaccination as a control for bovine Tuberculosis. ELife, 7, e27694. https://doi.org/10.7554/eLife.27694

Corner, L. A. L., Gormley, E., \& Pfeiffer, D. U. (2012). Primary isolation of Mycobacterium bovis from bovine tissues: Conditions for maximising the number of positive cultures. Veterinary Microbiology, 156(1-2), 162-171. https://doi.org/10.1016/j.vetmic.2011.10.016

Diallo, M., Diarra, B., Sanogo, M., Togo, A. C. G., Somboro, A. M., Diallo, M. H., Traoré, B., Maiga, M., Koné, Y., Tounkara, K., Sarro, Y. dit S., Baya, B., Goita, D., Kassambara, H., Dembélé, B. P. P., Siddiqui, S., Murphy, R. L., Dao, S., Diallo, S., ... Niang, M. (2016). Molecular identification of Mycobacterium bovis from cattle and human host in Mali: expanded genetic diversity. BMC Veterinary Research, 12(1), 145. https://doi.org/10.1186/s12917-016-0768-7

Eisenstadt, J., \& Hall, G. S. (1995). Microbiology and classification of mycobacteria. Clinics in Dermatology, 13(3), 197-206. https://doi.org/10.1016/0738-081X(95)00021-7

Gilsdorf, M. J., Ebel, E. D., \& Disney, T. W. (2006). Benefit and cost assessment of the US bovine tuberculosis eradication program. Mycobacterium Bovis Infections in Animals and Humans. 2nd Ed. Ames (IA): Blackwell Publishing, 89-99.

Gordon, S. V. (2008). Bovine TB: stopping disease control would block all live exports. Nature, 456(7223), 700. https://doi.org/10.1038/456700b

Katale, B. Z., Mbugi, E. V, Kendal, S., Fyumagwa, R. D., Kibiki, G. S., Godfrey-Faussett, P., Keyyu, J. D., Van Helden, P., \& Matee, M. I. (2012). Bovine tuberculosis at the human-livestock-wildlife interface: Is it a public health problem in Tanzania? A review. Onderstepoort Journal of Veterinary Research, 79(2), 84-97.

Krol, M., Brouwer, W., \& Rutten, F. (2013). Productivity Costs in Economic Evaluations: Past, Present, Future. PharmacoEconomics, 31(7), 537-549. https://doi.org/10.1007/s40273-013-0056-3

Lilenbaum, W, Pessolani, M. C. V, \& Fonseca, L. S. (2001). The Use of Ag85 Complex as Antigen in ELISA for the Diagnosis of Bovine Tuberculosis in Dairy Cows in Brazil. Journal of Veterinary 
Medicine, Series B, 48(3), 161-166. https://doi.org/10.1046/j.1439-0450.2001.00437.x

Lilenbaum, Walter, \& Fonseca, L. S. (2006). The use of ELISA as a complementary tool for bovine tuberculosis control in Brazil. Brazilian Journal of Veterinary Research and Animal Science.

Marassi, C.D., Medeiros, L., McNair, J., \& Lilenbaum, W. (2011). Use of recombinant proteins MPB70 or MPB83 as capture antigens in ELISAs to confirm bovine tuberculosis infections in Brazil. Acta Tropica, 118(2), 101-104. https://doi.org/10.1016/j.actatropica.2011.02.015

Marassi, Carla D., Medeiros, L., Figueiredo, E., Fonseca, L. S., Duarte, R., Paschoalin, V., Oelemann, W. M. R., \& Lilenbaum, W. (2013). A multidisciplinary approach to diagnose naturally occurring bovine tuberculosis in Brazil. Pesquisa Veterinária Brasileira, 33(1), 15-20. https://doi.org/10.1590/S0100736X2013000100004

Marassi, Carla D., Medeiros, L., \& Lilenbaum, W. (2010). The use of a Gamma-Interferon assay to confirm a diagnosis of bovine tuberculosis in Brazil. Acta Tropica, 113(2), 199-201. https://doi.org/10.1016/j.actatropica.2009.10.002

Medeiros, L., Marassi, C. D., Duarte, R. S., Silva, M. G., \& Lilenbaum, W. (2012). Comparison of decontamination methods for primary isolation of Mycobacterium bovis in paucibacillary bovine tissues. Letters in Applied Microbiology, 54(3), 182-186. https://doi.org/10.1111/j.1472-765X.2011.03185.x

Medeiros, Luciana S., Carvalho, Y. K., Maciel, R. C. G., \& Lilenbaum, W. (2016). Análise de custoefetividade de protocolos no diagnóstico da tuberculose bovina em um rebanho naturalmente infectado. Pesquisa Veterinária Brasileira, 36(6), 485-491. https://doi.org/10.1590/S0100736X2016000600005

Medeiros, Luciana S., Marassi, C. D., Figueiredo, E. E. ., Leite, J., Ferreira, A. M. R., \& Lilenbaum, W. (2012). Assessing the histopathology to depict the different stages of bovine tuberculosis infection in a naturally infected herd. Pesquisa Veterinária Brasileira, 32(2), 135-139. https://doi.org/10.1590/S0100736X2012000200008

Medeiros, Luciana Santos, Marassi, C. D., Figueiredo, E. E. S., \& Lilenbaum, W. (2010). Potential application of new diagnostic methods for controlling bovine Tuberculosis in Brazil. Brazilian Journal of Microbiology, 41(3), 531-541. https://doi.org/10.1590/S1517-83822010005000002

Monaghan, M. L., Doherty, M. L., Collins, J. D., Kazda, J. F., \& Quinn, P. J. (1994). The tuberculin test. Veterinary Microbiology, 40(1-2), 111-124. https://doi.org/10.1016/0378-1135(94)90050-7

Moraes, E., Campos, G. M., Figlie, N. B., Laranjeira, R. R., \& Ferraz, M. B. (2006). Conceitos introdutórios de economia da saúde e o impacto social do abuso de álcool. Revista Brasileira de Psiquiatria, 28(4), 321-325. https://doi.org/10.1590/S1516-44462006005000011

Mwacalimba, K. K., Mumba, C., \& Munyeme, M. (2013). Cost benefit analysis of tuberculosis control in wildlife-livestock interface areas of Southern Zambia. Preventive Veterinary Medicine, 110(2), 274-279. https://doi.org/10.1016/j.prevetmed.2012.10.020

Olea-Popelka, F., Muwonge, A., Perera, A., Dean, A. S., Mumford, E., Erlacher-Vindel, E., Forcella, S., Silk, B. J., Ditiu, L., El Idrissi, A., Raviglione, M., Cosivi, O., LoBue, P., \& Fujiwara, P. I. (2017). Zoonotic tuberculosis in human beings caused by Mycobacterium bovis - a call for action. The Lancet Infectious Diseases, 17(1), e21-e25. https://doi.org/10.1016/S1473-3099(16)30139-6

Palmer, M. V., Waters, W. R., Thacker, T. C., Greenwald, R., Esfandiari, J., \& Lyashchenko, K. P. (2006). Effects of Different Tuberculin Skin-Testing Regimens on Gamma Interferon and Antibody Responses in Cattle Experimentally Infected with Mycobacterium bovis. Clinical and Vaccine Immunology, 13(3), 387-394. https://doi.org/10.1128/CVI.13.3.387-394.2006

Piercy, J., Werling, D., \& Coffey, T. J. (2007). Differential responses of bovine macrophages to infection with bovine-specific and non-bovine specific mycobacteria. Tuberculosis, 87(5), 415-420. https://doi.org/10.1016/j.tube.2007.06.001

Pollock, J. M., \& Neill, S. D. (2002). Mycobacterium boviss Infection and Tuberculosis in Cattle. The Veterinary Journal, 163(2), 115-127. https://doi.org/10.1053/tvjl.2001.0655

Pollock, J. M., Welsh, M. D., \& McNair, J. (2005). Immune responses in bovine tuberculosis: Towards new strategies for the diagnosis and control of disease. Veterinary Immunology and Immunopathology, 108(12), 37-43. https://doi.org/10.1016/j.vetimm.2005.08.012 
Rangen, S. A., Surujballi, O. P., Lutze-Wallace, C., \& Lees, V. W. (2009). Is the gamma interferon assay in cattle influenced by multiple tuberculin injections? The Canadian Veterinary Journal $=L a$ Revue Veterinaire Canadienne, 50(3), 270-274. https://pubmed.ncbi.nlm.nih.gov/19436478

Rua-Domenech, R., Goodchild, A. T., Vordermeier, H. M., Hewinson, R. G., Christiansen, K. H., \& Clifton-Hadley, R. S. (2006). Ante mortem diagnosis of tuberculosis in cattle: A review of the tuberculin tests, $\gamma$-interferon assay and other ancillary diagnostic techniques. Research in Veterinary Science, 81(2), 190-210. https://doi.org/10.1016/j.rvsc.2005.11.005

Samuelson, W. F., \& Marks, S. G. (2012). Managerial Economics. John Wiley \& Sons.

Sancho, L. G. (2008). Revisitando a literatura sobre custo-efetividade e utilidade em saúde. Cadernos de Saúde Pública, 24(12), 2735-2746. https://doi.org/10.1590/S0102-311X2008001200002

Schiller, I., Oesch, B., Vordermeier, H. M., Palmer, M. V., Harris, B. N., Orloski, K. A., Buddle, B. M., Thacker, T. C., Lyashchenko, K. P., \& Waters, W. R. (2010). Bovine Tuberculosis: A Review of Current and Emerging Diagnostic Techniques in View of their Relevance for Disease Control and Eradication. Transboundary and Emerging Diseases, 64: 1493-1504. https://doi.org/10.1111/j.18651682.2010.01148.x

Secoli, S. R., Nita, M. E., Ono-Nita, S. K., \& Nobre, M. (2010). Avaliação de tecnologia em saúde: II. A análise de custo-efetividade. Arquivos de Gastroenterologia, 47(4), 329-333. https://doi.org/10.1590/S0004$\underline{28032010000400002}$

Segala, C. Z. S., \& Silva, I. T. (2007). Apuração dos custos na produção de leite em uma propriedade rural do município de irani-sc. Custos e @ Gronegócio on Line, 3(1), 61-83.

Silva, E. (2001). Evaluation of an enzyme-linked immunosorbent assay in the diagnosis of bovine tuberculosis. Veterinary Microbiology, 78(2), 111-117. https://doi.org/10.1016/S0378-1135(00)00282-0

Smith, N. H., \& Clifton-Hadley, R. (2008). Bovine TB: don't get rid of the cat because the mice have gone. Nature, 456(7223), 700. https://doi.org/10.1038/456700a

Sohn, H., Minion, J., Albert, H., Dheda, K., \& Pai, M. (2009). TB diagnostic tests: how do we figure out their costs? Expert Review of Anti-Infective Therapy, 7(6), 723-733. https://doi.org/10.1586/eri.09.52

Thoen, C. O., LoBue, P. A., Enarson, D. A., Kaneene, J. B., \& Kantor, I. N. (2009). Tuberculosis: a reemerging disease in animals and humans. Veterinaria Italiana, 45, 135-181.

Torgerson, P., \& Torgerson, D. (2008). Does risk to humans justify high cost of fighting bovine TB? Nature, 455(7216), 1029. https://doi.org/10.1038/4551029a

Torgerson, P., \& Torgerson, D. (2009). Benefits of stemming bovine TB need to be demonstrated. Nature, 457(7230), 657. https://doi.org/10.1038/457657d

Turner, A. (2011). Endemic disease control and regulation in Australia 1901-2010. Australian Veterinary Journal, 89(10), 413-421. https://doi.org/10.1111/j.1751-0813.2011.00811.x

Van Asseldonk, M. A. P. M., Van Roermund, H. J. W., Fischer, E. A. J., Jong, M. C. M., \& Huirne, R. B. M. (2005). Stochastic efficiency analysis of bovine tuberculosis-surveillance programs in the Netherlands. Preventive Veterinary Medicine, 69(1-2), 39-52. https://doi.org/10.1016/j.prevetmed.2005.01.012

Vanni, T., Luz, P. M., Ribeiro, R. A., Novaes, H. M. D., \& Polanczyk, C. A. (2009). Avaliação econômica em saúde: aplicações em doenças infecciosas. Cadernos de Saúde Pública, 25(12), 2543 2552. https://doi.org/10.1590/S0102-311X2009001200002

Vordermeier, M., Ameni, G., Berg, S., Bishop, R., Robertson, B. D., Aseffa, A., Hewinson, R. G., \& Young, D. B. (2012). The influence of cattle breed on susceptibility to bovine tuberculosis in Ethiopia. Comparative Immunology, Microbiology and Infectious Diseases, 35(3), 227-232. https://doi.org/10.1016/j.cimid.2012.01.003

Walzl, G., McNerney, R., Plessis, N., Bates, M., McHugh, T. D., Chegou, N. N., \& Zumla, A. (2018). Tuberculosis: advances and challenges in development of new diagnostics and biomarkers. The Lancet Infectious Diseases, 18(7), e199-e210. https://doi.org/10.1016/S1473-3099(18)30111-7

Wards, B. (1995). Detection of Mycobacterium bovis in tissues by polymerase chain reaction. Veterinary Microbiology, 43(2-3), 227-240. https://doi.org/10.1016/0378-1135(94)00096-F

Waters, W. R., Palmer, M. V, Thacker, T. C., Davis, W. C., Sreevatsan, S., Coussens, P., Meade, K. G., 
Hope, J. C., \& Estes, D. M. (2011). Tuberculosis Immunity: Opportunities from Studies with Cattle. Clinical and Developmental Immunology, 2011, 1-11. https://doi.org/10.1155/2011/768542

Wood, P. R., Corner, L. A., \& Plackett, P. (1990). Development of a simple, rapid in vitro cellular assay for bovine tuberculosis based on the production of $\gamma$ interferon. Research in Veterinary Science, 49(1), 46-49. https://doi.org/10.1016/S0034-5288(18)31044-0

Yahyaoui-Azami, H., Aboukhassib, H., Bouslikhane, M., Berrada, J., Rami, S., Reinhard, M., Gagneux, S., Feldmann, J., Borrell, S., \& Zinsstag, J. (2017). Molecular characterization of bovine tuberculosis strains in two slaughterhouses in Morocco. BMC Veterinary Research, 13(1), 272. https://doi.org/10.1186/s12917-017-1165-6

Yates, G. F., Price-Carter, M., Bland, K., Joyce, M. A., Khan, F., Surrey, M., \& Lisle, G. W. (2017). Comparison of the BBL mycobacteria growth indicator tube, the BACTEC 12B, and solid media for the isolation of Mycobacterium bovis. Journal of Veterinary Diagnostic Investigation, 29(4), 508512. https://doi.org/10.1177/1040638717697763

Zumárraga, M. J., Soutullo, A., García, M. I., Marini, R., Abdala, A., Tarabla, H., Echaide, S., López, M., Zervini, E., Canal, A., \& Cataldi, A. A. (2012). Detection of Mycobacterium bovis -Infected Dairy Herds Using PCR in Bulk Tank Milk Samples. Foodborne Pathogens and Disease, 9(2), 132 137. https://doi.org/10.1089/fpd.2011.0963

Article History:

Received: 1 July 2020.

Accepted 5 August 2020

Available online: 25 October 2020.
License information: This is an open-access article distributed under the terms of the Creative Commons Attribution License 4.0, which permits unrestricted use, distribution, and reproduction in any medium, provided the original work is properly cited. 